\title{
Ерготерапія як засіб розвитку незалежності осіб із тяжкими порушеннями зору та сліпотою в санаторно-курортних умовах
}

\author{
УДК 615.851.3-056.262:614.215 \\ Я. М. Копитіна', А. В. Єрмолаєва² \\ ${ }^{1}$ Навчально-науковий інститут фізичної культури, Сумський державний \\ педагогічний університет імені А. С. Макаренка, Суми, Україна \\ ${ }^{2}$ Національний університет «Запорізька політехніка», Запоріжжя, Україна
}

Резюме. Сліпота та складні порушення зору значною мірою ускладнюють щоденне побутове життя людей. На сьогодні одним із засобів розвитку незалежності таких осіб є ерготерапія. Мета. Визначити особливості впливу застосування ерготерапії для формування незалежного життя осіб із важкими порушеннями зору та сліпотою в санаторно-курортних умовах. Методи. Педагогічне спостереження, навчання, методи фізичної терапії. Результати. Під час курсу ерготерапії було проведено ознайомлення з інфраструктурою бази за допомогою мнемосхем, здійснено навчання з технік правильного супроводу осіб з інвалідністю по зору у коридорах, дверях, ліфті, сходами, в їдальні, спортивному залі, на вулиці, у громадському транспорті; проведено перевірку відповідності довжини тактильної тростини зросту її користувача; навчання та удосконалення техніки володіння тактильною тростиною методами «ковзання», «дотику», «маятника». Реабілітантів навчали користуватися ліфтом, який має звуковий орієнтир поверху та підписані кнопки тактильним шрифтом Брайля. Проводили навчання орієнтування методом «годинникового циферблата» та використання його під час переміщення базою і під час прийому їжі; вчили готувати напої із застосуванням звукового індикатора рівня рідини. Проводили заняття з опанування сенсорних ґаджетів та електронних додатків, які допомагають вирішити побутові проблеми. Проведено тренування у визначенні звукових та тактильних орієнтирів-маячків для пересування, підвищено рівень обізнаності про особливості допомоги у переміщенні незрячих або слабкозорих осіб за допомогою поводиря. Застосування засобів ерготерапії у рамках двотижневої програми фізичної терапії дало можливість проаналізувати характерні побутові проблеми слабкозорих та незрячих осіб з інвалідністю і знайти шляхи вирішення цих проблем без сторонньої допомоги, формуючи віру у свої можливості, самостійність та незалежність.

Ключові слова: ерготерапія, незрячі особи, слабкозорі особи, незалежність, фізична терапія, санаторно-курортні умови.

Ergotherapy as a means of developing the independence of people with severe visual impairments and blindness in sanatorium conditions

\section{M. Kopytina', A. V. Iermolaieva ${ }^{2}$}

${ }^{1}$ Educational and Scientific Institute of Physical Culture, A.S. Makarenko Sumy State Pedagogical University, Sumy, Ukraine

2 Zaporizhzhia Polytechnic National University, Zaporizhzhia, Ukraine

Abstract. Blindness and complex visual impairments significantly complicate people's daily lives. Today, one of the means of developing the independence of such persons is ergotherapy. Objective. To determine the features of the impact of ergotherapy usage on the formation of independent life of persons with severe visual impairment and blindness in sanatorium conditions. Methods. Pedagogical observation, training, methods of physical therapy. Results. In the course of ergotherapy, the infrastructure of the base was acquainted with the help of mnemonics, training was provided on techniques for proper support of visually impaired people in corridors, doors, elevators, stairs, dining room, gym, on the street, in public transport; the compliance of the length of the tactile cane with the height of its user was checked; training and improvement of tactile cane technique by methods of "sliding", "touch", "pendulum" was carried out. Rehabilitants were taught to use the 
elevator, which has a sound landmark of the floor and signed buttons in tactile Braille. Orienteering training using the "clock face" method and its use during the movement along the base and during meals was conducted; rehabilitants were taught to prepare drinks using a sound liquid level indicator. Classes were held on mastering sensory gadgets and electronic applications that help solve household problems. Training was provided in determining sound and tactile landmarks-beacons for movement, the level of awareness about the features of assistance in moving blind or partially sighted people with the help of a guide was raised. The use of ergotherapy in a two-week physical therapy program permitted to analyze the typical domestic problems of visually impaired and blind people with disabilities and find ways to solve these problems without assistance, forming faith in their capabilities, independence and autonomy.

Keywords: ergotherapy, blind people, visually impaired people, independence, physical therapy, sanatorium conditions.

Постановка проблеми. Здоровий зір для людей будь-якого віку завжди залишався надзвичайною цінністю. На сьогодні, за різними статистичними даними, в Україні налічується близько 300 тис. незрячих та слабкозорих громадян. Сліпота та складні порушення зору значною мірою ускладнюють щоденні побутові та професійні обов'язки, адже зоровий аналізатор здійснює контроль над рухами тіла людини, тому що він на $80 \%$ допомагає сприймати навколишнє середовище [1].

У доступних нам літературних джерелах, де розглядалися питання ерготерапії для слабкозорих та незрячих осіб, було відзначено наявність наукових робіт, у яких висвітлено застосування ерготерапії для дітей з порушеннями зору [2]; для формування незалежності під час навчання школярів [7]; особливості застосування ерготерапії для осіб похилого віку зі зниженим зором $[3,6]$; застосування ерготерапії для покращення мобільності осіб похилого віку зі зниженим зором [5]; для покращення дозвілля та соціальної активності осіб похилого віку зі слабким зором $[4,8]$; для покращення читацьких здібностей в осіб похилого віку зі слабким зором [9]. Проаналізувавши отриману інформацію, було зроблено висновок про недостатнє вивчення питання формування незалежності в осіб із тяжкими порушеннями зору та сліпотою працездатного віку засобами ерготерапії.

Часткове зниження гостроти зору (9D90.19D90.3) або повна сліпота (9D90.4-9D90.5) спричиняють ряд побутових незручностей для досягнення короткочасних та довготривалих цілей. Так, значно будуть ускладнюватися та займатимуть більше часу на здійснення процедури вибору і закупівлі продуктів та/або одягу у магазинах; вдягання необхідного одягу (вибір шкарпеток однакового кольору, диференціація чистих-брудних елементів одягу, виявлення ступеня забрудненості і визначення результативності прання, безпечне прасування); навігація містом, на робочому місці та вдома; користуван- ня необхідними гаджетами; приготування та вживання їжі; відвідування громадських і релігійних закладів; участь у суспільному, культурному, політичному, духовному житті громади; здійснення особистої гігієни і догляд за дітьми; виконання хатньої роботи та догляд за домашніми тваринами.

Вказані аспекти повсякденного сучасного життя не викликають значних труднощів у тих осіб, які мають вроджені або набуті у ранньому дитинстві порушення зору. Після досягнення 17 років (саме з цього віку ми включили у групи реабілітантів для участі у спортивно-реабілітаційних зборах) у слабкозорих та незрячих осіб з інвалідністю відзначається вищий ступінь незалежності від членів родини та оточуючого середовища. Навчання у спеціалізованих навчальних закладах, робота тифрлопедагогів і психологів створюють досить якісну базу для подальшого розвитку особистості, прояву її незалежності. $Є$ й винятки, які, зазвичай, представлені особами з інвалідністю по зору з наявністю ментальних порушень або захворювань. Відсутність внутрішньої мотивації до самостійного, незалежного життя, наявність досить активних членів сім'ї, які вважають місією усього свого життя служіння слабкозорому чи незрячому члену родини з метою максимально швидко задовольнити усі його потреби, створюють значні ускладнення у фрормуванні потреби у незалежності. Найчастіше люди з інвалідністю по зору, маючи таку цілодобову «допомогу» близьких, зовсім не пристосовані до самостійного життя, іноді навіть самі не їдять (їх годують з ложечки, щоб не розлити та не забруднитися), їм перуть та прасують одяг, допомагають одягатися, здійснювати елементарні гігієнічні процедури, повсюди супроводжують та, звичайно, обмежують коло спілкування. Вважаємо за доцільне зазначити, що ця категорія реабілітантів $\epsilon$ найбільш складною через низьку внутрішню вмотивованість, а також наявність впевненості та надії у тому, що найближче оточення завжди має і буде їм допомагати. 
Зовсім інша ситуація відбувається з тими особами, які втратили зір у дорослому віці через хворобу (вроджену або набуту), травми чи бойові поранення. Той фракт, що лише вчора людина була самостійною і незалежною, а сьогодні стає тотально незрячою або з малим залишком зору, втрачає можливість продовжувати навчання чи займатися своєю звичною професійною діяльністю, потребуючи постійної допомоги членів родини, викликає шок, депресію та може формувати думки про самогубство. Незважаючи на це, такий контингент реабілітантів старанно вчиться самостійно здійснювати спочатку елементарні побутові речі, а потім і більш складні та, на перший погляд, неможливі завдання.

Дослідження виконано відповідно до колективної науково-дослідної теми кафедри здоров'я, фрізичної терапії, реабілітації та ерготерапії Навчально-наукового інституту фрізичної культури Сумського державного педагогічного університету імені А. С. Макаренка на 2020-2025 рр. «Теоретико-методологічні і організаційно-методичні проблеми здоров'я, фрізичної терапії, реабілітації, ерготерапії та спеціальної освіти» (номер держреєстрації 0120U100803).

Мета дослідження - визначити особливості впливу застосування ерготерапії для фрормування незалежного життя осіб із важкими порушеннями зору та сліпотою в санаторно-курортних умовах.

Методи й дослідження: педагогічне спостереження, навчання, методи фрізичної реабілітації.

Результати дослідження та їх обговорення. У дослідженні взяли участь 289 осіб 17-46 років, які мають тяжкі порушення зору або сліпоту. Реабілітантів 17-21 року було 34 особи $(11,8 \%), 22-35$ років - 234 особи (81\%), 36-55 років - 21 особа (7,41\%). Середній вік реабілітантів становив 29,3 $\pm 6,1$ року. Із залишком зору реабілітантів було 178 осіб (61,6 \%), тотально незрячих - 111 осіб $(38,4$ \%). Інвалідність першої групи була встановлена у 222 осіб (76,8 \%), друга група інвалідності - у 67 осіб $(23,2 \%)$. На момент написання даного наукового доробку фрізичну терапію пройшли 159 жінок (55\%) та 130 чоловіків (45\%).

Вони проходили курси фрізичної терапії на базі Західного реабілітаційно-спортивного центру Національного комітету спорту інвалідів України (с. Яворів, Турківський р-н, Львівська обл.) 3 2016 по 2020 р.

Щороку для участі у реабілітаційно-спортивних зборах із метою розширення адаптаційних можливостей та оволодіння ширшим спектром засобів фрізичної терапії й ерготерапії у різних погодних та температурних умовах проводили по два заїзди - літній та зимовий, обидва тривалістю по два тижні. Зазвичай, у теплу пору року заїзди формувалися із 40 учасників реабілітаційного процесу та 20 тренерів; у холодну пору року - з 20 та 10 осіб відповідно.

Списки реабілітантів фрормували таким чином, щоб кожна бажаюча особа з тяжкими порушеннями зору мала змогу двічі пройти курс фрізичної реабілітації - влітку та взимку. Заявки на участь у реабілітаційно-спортивних заїздах надсилалися потенційними учасниками самостійно та добровільно. Проїзд, проживання, харчування та сам реабілітаційний процес на усіх заїздах для усіх реабілітантів були безкоштовні.

Протягом усього курсу фрізичної терапії проводили педагогічне спостереження за тим, як реабілітанти взаємодіяли один з одним, здійснювали самообслуговування, проявляли ступінь відчуття незалежності та незалежного життя від родичів/близьких; спостерігали за здатністю самостійно знаходити необхідні у побуті речі та використовувати їх без сторонньої допомоги, використовувати для орієнтування метод «годинникового циферблата», застосовувати електронні ґаджети та електронні додатки відповідно до індивідуальних потреб.

Для досягнення мети з реабілітантами працювала мультидиспиплінарна команда, яка складалася 3 фрізичних терапевтів, ерготерапевтів, психологів, тренерів зі скандинавської ходьби, туризму, велосипедного спорту, з просторового орієнтування та електронних гаджетів. Усі тренери працювали узгоджено між собою та доповнювали один одного.

За особливостями географрічного поділу реабілітанти були з: Одеської та Львівської обл. по 38 осіб (13,2 \%), Київської обл. - 28 осіб $(9,7$ \%), Черкаської обл. - 25 осіб $(8,7$ \%), Харківської та Хмельницької обл. - по 15 осіб $(5,2 \%)$, Кіровоградської обл. - 14 осіб (4,9\%), Волинської та Полтавської обл. - по 13 осіб $(4,5 \%)$, Рівненської обл. - 10 осіб (3,5 \%), Івано-Франківської обл. - 9 осіб (3,1 \%), Дніпропетровської та Житомирської обл. - по 8 осіб $(2,8$ \%), Закарпатської, Запорізької, Чернігівської, Херсонської обл. та підконтрольної Україні території Донецької обл. - по 7 осіб (2,4%), Сумської обл. - 6 осіб (2,1%), Тернопільської обл. - 5 осіб (1,7 \%), підконтрольної Україні території Луганської обл. - 4 особи (1,4 \%), Чернівецької обл. -3 особи (1,1\%), Вінницької обл. - 2 особи $(0,7 \%)$.

Первинне дослідження виявило ряд типових щоденних проблем через брак або повну відсутність зору: 
1. Помилки у застосуванні тактильної тростини. Здебільшого ця проблема виявлялася в осіб, які нещодавно стали використовувати ії для переміщення, незалежно від віку реабілітанта. Виявлені критичні помилки у фріксації тростини рукою - одягання ремінця на зап'ястя, а не на мізинець, що $є$ вельми небезпечним у випадку потрапляння тростини під рухомий транспортний засіб, внаслідок чого особа з інвалідністю, не встигнувши зняти ремінець із зап'ястка, може отримати травми, потрапивши під колеса. В одного учасника спортивно-реабілітаційних зборів було виявлено замість тактильної тростини ортопедичну, яку видали за державні кошти у відділі соціальних допомог Управління праці та соціального захисту населення. Початківці - користувачі тактильними тростинами - робили помилки у визначенні тактильних орієнтирів, неправильно підбирали висоту тростини відносно власного зросту. Відзначалися випадки неправильного поводження з тростиною (відмова у складанні тростини у тих місцях, де вона може заважати іншим членам суспільства, наприклад у їдальні).

2. Помилки під час переміщення сходами та вулицею, які виникають при неправильному користуванні тактильною тростиною.

3. Потреба у допомозі сторонніх осіб під час приготування та вживання їжі. Було зафріксовано відмови від здійснення таких побутових дій, як сервірування столу, визначення розташування та пошук на столі необхідного посуду, вживання страв, які потребують застосування столових приборів (салати, м'ясо тощо). Реабілітанти, які мали гіперопіку членів своїх родин, чекали, поки їм подадуть тарілки з їжею, допоможуть підготувати прибори та погодують. Також було зафріксовано відмови від вживання риби у раціоні харчування через побоювання вдавитися кісточками.

4. Складнощі під час вибору одягу та процесу вдягання. Вдягання однакових за кольором шкарпеток чи підбір доцільного одягу та взуття (наприклад, взування на ранкову гігієнічну гімнастику не кросівок, а босоніжок, тапок чи пантофрель - того, що першим знайшли у кімнаті) вимагало більших затрат часу, сил та напруження пам'яті.

5. Низький рівень інформованості про можливості електронних додатків та ґаджетів, що полегшують побутове життя людям, які мають інвалідність по зору.

6. Недосконале володіння технікою читання за шрифртом Брайля або повна його відсутність.

Оскільки ерготерапія має бути спрямована на повернення людини до повсякденної діяльності та суспільного життя з урахуванням ії особистих потреб і бажань, то у контексті зазначеного контингенту ерготерапію використовували у всіх сорерах щоденної активності реабілітантів, що сприяло досягненню точності виконаних рухів шляхом багаторазових повторень та тифрлокоментаря дій.

Усі завдання, які вирішували за допомогою ерготерапії, були не гіпотетичні, а ситуативні. Ми впевнені у тому, що суто механічна м'язова діяльність $\epsilon$ неефективною і лише врахування реальних потреб та можливостей учасників реабілітаційного процесу надає результативності ерготерапевтичної інтервенції, оскільки кожен вид заняттєвої активності мав конкретну мету.

На початку кожного заїзду учасникам реабілітаційного процесу провели екскурсію по всій базі $з$ метою ознайомлення $з$ інфраструктурою та формування просторового уявлення про місцезнаходження реабілітантів. Будівлі та прилегла територія Західного реабілітаційно-спортивного центру $\epsilon$ зразком відповідності європейським нормам щодо державних будівельних норм із точки зору доступності усіх приміщень для маломобільних груп населення, на кожному поверсі $\epsilon$ відповідні мнемосхеми для полегшення орієнтування та вивчення загальної концепції будівлі і території для активної спортивної діяльності. Також $€$ каталог мнемосхем лижних трас із зазначенням складності, довжини траси та кута набору висоти, якими користуються відвідувачі центру. Із мнемосхемами знайомилися на початку заїздів, але за потреби реабілітанти вивчали їх повторно.

На початку заїздів також здійснювали навчання технік правильного супроводу осіб у різних умовах приміщень (коридори, двері, ліфт, сходи, їдальня, спортивний зал), на вулиці, у громадському транспорті. Окремо виносили на обговорення правила поведінки у спортивному залі, на лижних трасах, у сауні з метою запобігання травматизму.

Виходячи 3 нагальних побутових проблем, було проведено перевірку відповідності довжини тростини зросту іiї користувача; порівняно різні моделі тростин та здійснено консультування 3 пошуку оптимального індивідуального варіанту моделі; проведено навчання та удосконалення техніки володіння тактильною тростиною методами «ковзання», «дотику», «маятника»; було скореговано помилки під час тримання тростини; реабілітанти навчалися та удосконалювали рух сходами з використанням тактильної тростини; вивчили підписи тактильним шрифтом Брайля нумерації поверхів, які розміщені на усіх перилах сходових прольотів. 
Реабілітанти навчалися користуватися ліфтом, який має звуковий орієнтир поверху та підписані тактильним шрифтом Брайля кнопки. Цю складову частину занять проводили спочатку малогруповим методом, а у подальшому реабілітантів спонукали до самостійного пересування базою. Спершу ці спроби вимагали витрати значного часу і реабілітанти інтуїтивно намагалися групуватися за тим принципом, що особа із залишком зору, або той, хто гарно орієнтується у просторі, були супроводжуючою особою у тотально незрячих чи тих, хто погано орієнтується у просторі та на території самого центру. Для запобігання такій «допомозі» зробили розподіл загальної групи реабілітантів на підгрупи, де у кожній був свій окремий розклад, давали індивідуальні завдання та робили нетривалі перерви між заняттями, що вимагало від учасників реабілітаційного процесу бути незалежними від інших, самостійними, мобільними та відповідальними за свої дії.

Проводили навчання орієнтування методом «годинникового циферблата» та використання його під час переміщення базою і прийому їжі; вчили готувати напої без побоювання отримати опік гарячою рідиною чи пролити напій за допомогою використання звукового індикатора рівня рідини $[1,15]$, самостійно користуватися столовими приборами та обслуговувати себе за столом (наливати із супниці перші страви, заварювати чай, користуватися ложками, виделками, ножами, а не їсти руками) і під час піших туристичних походів.

Проводили заняття з опанування сенсорних гаджетів та електронних додатків, які допомагають полегшити навігацію містом (додаток супутникової навігації «Lazarillo GPS for Blind») [13]; розпізнавати візуальні об'єкти та їх кольори, трансформувати написаний, навіть рукописний текст або нотатки у формат мовлення, використовувати електронне збільшуване скло (додаток «Envision») [11]; встановлювати зв'язок із волонтерами при виникненні будь-якої проблеми, яка формується через брак зору (додаток «Ве Му Eyes») [10]; розпізнавати номінали валют (додаток MCT Money Reader) [14]; озвучувати екрани телефонів за допомогою жестової навігації, які працюють на операційній системі Android (додаток «TalkBack») [17]; озвучувати екрани та інтерфейси на продукції компанії Apple, такі як iOs, WatchOs, iPadOs, TiviOs, за допомогою жестової навігації (додаток «VoiceOver») [12]; читати електронні книги в аудіоформаті (додаток «Vоісе Dream Reader») [16]; систематизувати та маркувати будь-які побутові речі (цифровий маркердиктофрон «Touch Memo») [1, 18].
Протягом курсу фрізичної реабілітації пацієнти оволоділи таким спортивним інвентарем, як фрітболи, фрітнес-гумки, спортивні тренажери; навчилися техніки скандинавської ходьби, їздити на велосипеді-тандемі, розбивати наметове містечко.

Роботу проводили не лише 3 реабілітантами, а й з членами їхніх родин, оскільки одне із завдань ерготерапевта - це робота з родиною пацієнта як із першим середовищем, куди реабілітант повернеться після завершення реабілітаційно-спортивного заїзду. Ми виділили такі вектори співпраці з членами сімей:

1) підвищення рівня обізнаності про особливості допомоги під час переміщення незрячих або слабкозорих осіб за допомогою поводиря (особа з порушеннями зору має триматися за лікоть або нижню третину плеча супроводжуючої особи, замість того щоб обом триматися за руки, або під час руху колоною один за одним рука слабкозорого розміщується на плечі супроводжуючої особи; користуючись дверями, ліфртом, транспортними засобами, першою заходить/виходить до приміщення або кімнати супроводжуюча особа з метою опису розташування та габаритів дверних пройомів, а не штовхає поперед себе слабкозору чи незрячу особу);

2) допомога у визначенні звукових (шум машин, звуки світлофора, музика, тиша, звуковий маяк тощо) та тактильних (бордюри, фрундамент, тактильна поверхня, плитка, килим, асфральтоване покриття, трава, бруківка, надписи тактильним шрифртом Брайля, мнемосхеми тощо) орієнтирівмаячків для пересування;

3) підвищення рівня знань про можливості та реалії застосування допомоги собак-поводирів.

Вважаємо за доцільне зазначити, що ті реабілітанти, які втратили зір відносно недавно, вже у дорослому віці, були гірше пристосовані до самостійного життя, ніж ті, які були незрячі чи слабкозорі з народження або з дитинства.

Педагогічне спостереження зафіксувало, що перші 2-3 дні реабілітанти переміщувалися по центру лише групами, на які вони були попередньо розподілені організаторами заходу. Виняток становили сімейні пари - вони не боялися відокремитися від своєї групи та здійснювали переміщення по центру, допомагаючи один одному.

Через 5-7 днів відбувалися спроби самостійного пересування центром, оскільки реабілітанти вже вивчили інфраструктуру і знали план розміщення приміщень та місця, підписані шрифтом Брайля. Принцип безбар'єрного простору, який було покладено в основу проєктування Західного реабілітаційно-спортивного центру, дозволив 
значно полегшити користування усіма необхідними приміщеннями та зонами. У цей час курсу фрізичної терапії реабілітанти допускали значну кількість помилок, проте намагалися робити все самостійно.

Об'єктивною оцінкою розвитку незалежності наприкінці курсу фрізичної терапії став той фракт, що реабілітанти почали використовувати тактильно-звукові орієнтири та удосконалили використання тактильної тростини, навчилися обслуговувати себе в їдальні. Кожен із реабілітантів навчився самостійно пересуватися у приміщеннях та на вулиці без сторонньої допомоги.

Для контролю засвоєння усіх складових програм ерготерапії було організовано виїзні екскурсії (м. Ужгород, Івано-Франківськ, місцева сирна ферма або пасіка), проведено піші туристичні походи (на 3,5, 5, 6, 10 км) $з$ метою ви-

\section{Література}

1. Копитіна ЯМ. Особливості застосування електронних засобів комунікації у системі ерготерапії слабозорих та незрячих осіб [Features of the use of electronic communication means in the system of ergotherapy of the visually impaired and blind users]. Україна. Здоров'я нації. 2020; 3/1 (61): 112-118.

2. Aki E, Atasavun S, Turan A, \& Kayihan H. Training Motor Skills of Children with Low Vision. Perceptual and Motor Skills. 2007; 104(3_suppl): 1328-1336. https://doi.org/10.2466/pms.104.4.1328-1336.

3. Berger S. Effectiveness of Occupational Therapy Interventions for Older Adults Living With Low Vision. American Journal Occupattion Therapy. 2013; 67(3): 263-265. https://doi.org/10.5014/ajot.2013.007203.

4. Berger S, McAteer J, Schreier K, Kaldenberg J. Occupational Therapy Interventions to Improve Leisure and Social Participation for Older Adults With Low Vision: A Systematic Review. American Journal Occupattion Therapy. 2013; 67(3): 303-311. https://doi.org/10.5014/ajot.2013.005447.

5. Brouwer DM, Sadlo G, Winding K, \& Hanneman M I G. Limitations in Mobility: Experiences of Visually Impaired Older People. British Journal of Occupational Therapy. 2008; 71(10): 414-421. https://doi. org/10.1177/030802260807101003.

6. Kaldenberg J, Smallfield S. Occupational Therapy Practice Guidelines for Older Adults With Low Vision. American Journal Occupattion Therapy.2020; 74(2): 154-159. https://doi.org/10.5014/ajot.2020.742003.

7. Lewis S, \& Iselin SA. A Comparison of the Independent Living Skills of Primary Students with Visual Impairments and Their Sighted Peers: A Pilot Study. Journal of Visual Impairment \& Blindness.2002; 96(5): 335-344. https:/l doi.org/10.1177/0145482X0209600505.

8. Nastasi JA. Occupational Therapy Interventions Supporting Leisure and Social Participation for Older Adults With Low Vision: A Systematic

yana@kopytin.in.ua

alyermolaieva7777@gmail.com значення ступеня готовності та прояву своєї незалежності. В останній день заїздів проводили підсумкові змагання команд - квести, на яких необхідно було максимально якісно та швидко проявити усі отримані під час проходження курсу ерготерапії навички із самостійного орієнтування та самообслуговування.

Висновки. Застосування засобів ерготерапії у рамках двотижневої програми фрізичної терапії дало можливість проаналізувати характерні побутові проблеми слабкозорих та незрячих осіб і знайти шляхи вирішення цих проблем без сторонньої допомоги, фрормуючи віру у свої можливості, самостійність та незалежність.

Перспективи подальших досліджень полягають в аналізі заняттєвого профрілю самостійних видів щоденної діяльності осіб з інвалідністю, які мають тяжкі порушення зору або сліпоту.

Review. American Journal Occupattion Therapy. 2019; 74(1): 185-20. https:// doi.org/10.5014/ajot.2020.038521.

9. Smallfield S, Clem K, Myers A. Occupational Therapy Interventions to Improve the Reading Ability of Older Adults With Low Vision: A Systematic Review. American Journal Occupattion Therapy. 2013; 67(3): 288-295. https:// doi.org/10.5014/ajot.2013.004929.

10. Internet Be My Eyes [Електронний ресурс]. - Режим доступу: https://www.bemyeyes.com/language/russian (дата звернення: 20.11.2020).

11. Internet Envision [Електронний ресурс]. - Режим доступу: https:// ru.letsenvision.com/ (дата звернення: 20.11.2020).

12. Internet iPhone [Електронний ресурс]. - Режим доступу: https:// www.apple.com/ru/accessibility/iphone/vision/ (дата звернення: 20.11.2020).

13. Internet Lazarillo [Електронний ресурс]. - Режим доступу: https:// www.lazarillo.app/en/ (дата звернення: 20.11.2020).

14. Internet MCT Money Reader [Електронний ресурс]. - Режим доступу: https://play.google.com/store/apps/details?id=com.mctdata.ParaTanima\&hl=en (дата звернення: 20.11.2020).

15. Internet SmartAIDs [Електронний ресурс]. - Режим доступу: https://www.smartaids.ru/catalog/product/indikator-urovnya-zhidkosti-zvukovibratsionnyy/ (дата звернення: 20.11.2020).

16. Internet Voice dream [Електронний ресурс]. - Режим доступу: https://www.voicedream.com/ (дата звернення: 20.11.2020).

17. Internet Специальные возможности для Android [Електронний ресурс]. - Режим доступу: https://play.google.com/store/apps/details?id=com. google.android.marvin.talkback\&hl=ru (дата звернення: 20.11.2020).

18. Internet Элита групп [Електронний ресурс]. - Режим доступу: https://www.elitagroup.ru/pages/prod-TouchMemo.php (дата звернення: 20.11.2020). 